\title{
COMBUSTION ENGINE POWERED BY A MIXTURE OF NATURAL GAS AND HYDROGEN
}

\author{
ANDREJ CHRÍBIK, MARIÁN POLÓNI, JÁN LACH \\ Slovak University of Technology in Bratislava, Faculty of Mechanical Engineering \\ Námestie slobody 17, 81231 Bratislava, Slovakia \\ E-mail: andrej.chribik@stuba.sk, marian.poloni@stuba.sk, jan.lach@stuba.sk
}

\begin{abstract}
SHRNUTí
Predkladaný článok sa zaoberá vplyvom primiešavania vodíka do zemného plynu ( $\mathrm{H} 2 \mathrm{NG}-0 \%, 10 \%, 20 \%, 30 \%$ obj. $\left.\mathrm{H}_{2}\right)$ na výkonové, ekonomické a emisné parametre spal'ovacieho motora Lombardini LGW 702. Experimentálne merania boli vykonané pri rôznom zložení zmesi a v širokom rozsahu otáčok. Z nameraných dát sa určila optimalizačná mapa uhla predstihu zapal'ovania od podielu vodíka v zmesi za účelom dosiahnutia maximálneho točivého momentu. V dálšej časti je popísaná analýza tlakov v spal'ovacom priestore, ktorá nám poskytuje dôležité údaje o dosiahnutom maximálnom tlaku, rýchlosti nárastu tlaku, charakteru spalovacieho procesu a množstve dálších údajov charakterizujúcich danú zmes (H2NG). V poslednej časti je ukázaný vplyv prímesi vodíka na charakter zloženia výfukových plynov $\left(\mathrm{CO}, \mathrm{CO}_{2}, \mathrm{O}_{2}, \mathrm{NO}_{x}\right)$.
\end{abstract}

KLIĆCOVÁ SLOVA: ZÁŽIHOVÝ MOTOR, ZMES PLYNOV, TLAK VO VALCI, PARAMETRE MOTORA

\section{ABSTRACT}

The present article deals with the influence of blending hydrogen into natural gas ( $\mathrm{H} 2 \mathrm{NG}-0 \%, 10 \%, 20 \%, 30 \%$ vol. $\mathrm{H}_{2}$ ) and how the blending influences the performance, emissions and economic parameters of an LGW 702 combustion engine. The experimental measurements were performed for various mixture compositions and various air excess ratios over a wide speed range. The analysis of pressures in the combustion engine provides important data on maximum pressure, increase in pressure, characteristics of the combustion process and many other data characterizing the given blend (H2NG). The final part shows the effect of the hydrogen admixtures on the composition of exhaust gases $\left(\mathrm{CO}_{1} \mathrm{CO}_{2^{\prime}} \mathrm{O}_{2^{\prime}} \mathrm{NO}_{\mathrm{x}}\right)$.

KEYWORDS: SPARK IGNITION ENGINE, GAS BLEND, CYLINDER PRESSURE, ENGINE PARAMETERS

\section{INTRODUCTION}

With the increasing concerns about energy shortage and environmental protection, the interest of the professional community is concentrating on the utilisation of alternative sources of energy to power the internal combustion engine. One of the most promising gaseous fuels seems to be natural gas. The main component of natural gas is methane (over $98 \%$ ) with calorific value $50 \mathrm{MJ}^{\mathrm{kg}}{ }^{-1}$ and octane number 130, which makes it a suitable internal combustion engine fuel. However, burning occurs with a high ignition temperature $\left(540^{\circ} \mathrm{C}\right)$ and low flame propagation speed, and these aspects lead to poor combustion particularly in lean mixture areas, thus to overall slow burning. This results in greater susceptibility to incomplete combustion, a high degree of ignition failure and a negative impact on the cycle variability. One possible solution to these problems may be the utilisation of a fuel with properties that can eliminate the negative effects associated with burning natural gas. The preferred fuel option appears to be hydrogen with its fast burning and lower spark energy requirement. This leads to a lower ignition temperature, which in turn contributes both to the enhanced nature of combustion and has a positive effect on the emission parameters. This contribution deals with utilisation of these two types of fuel in a spark-ignition engine primarily designed to drive micro-cogeneration units.

\section{CHARACTERISTICS OF A H2NG MIXTURE}

The internal combustion engine fuel is a gas mixture with various proportions of hydrogen content, which has a general designation H2NG. In our experimental measurements we added hydrogen stored in cylinder flask (up to $30 \%$ vol.) to the main current of natural gas. The actual admixing was carried out before the gas enters the diffuser. Table 1 shows the basic properties of mixture combinations of natural gas and hydrogen. 
As seen from Table 1, with increasing proportion of hydrogen in natural gas there occurs a rise in the lower calorific value, but as the mass conversely decreases, the calorific value of the mixture also decreases. The result is that under delivery of a stoichiometric amount of fuel, with the increasing percentage of hydrogen the amount of released heat contained in the fuel decreases. Adding hydrogen increases the threshold of flammability of the mixture. For natural gas, the interval for excess air ratio $\lambda$ under atmospheric conditions ranges from 0.57 to 1.92 , while for $30 \% \mathrm{H}_{2}$ this limit increases, particularly in the lean mixture burning to the range $\lambda 0.52$ to 2.67 . Increasing the proportion of hydrogen reduces the ignition delay time and increases the combustion velocity. An admixture of hydrogen also has a positive impact on the composition of exhaust gas and effective efficiency, which will be listed below.

\section{LOMBARDINI LGW 702 ENGINE}

In order to reduce operating costs (fuel consumption) the basic analysis of the impact of mixture composition on the parameters of the internal combustion engine was performed on a two-cylinder Lombardini LGW 702 gasoline engine, which is the basic power unit for micro-cogeneration units. The fuel-air mixture was prepared in a mixer equipped with a diffuser. The stoichiometric composition of the mixture was controlled by a Voila electronic unit. Basic parameters of the engine are shown in Table 2.

\section{ANALYSIS OF PRESSURE IN THE COMBUSTION CHAMBER}

Combustion pressure analysis was performed with a pressure plug (spark plug with piezoelectric sensor) using the Kistler system. A pressure plug gives us information only on the relative pressure in the combustion chamber, and therefore it was necessary to perform a pressure correction in order to obtain the absolute pressure. This correction was performed on the basis of measured pressures within the intake manifold, with the intake valve open and the piston near bottom dead centre (BDC). Ignition advance angle was set to $32^{\circ} \mathrm{CA}$ before TDC (Figure 1). This adjustment is rather unusual, but the reason for it was to increase the differences in peak cylinder pressures and also to eliminate some negative effects (backfire into the intake manifold) with the given thermal value of the spark plug in this experiment. The measurement was performed at speed $1200 \mathrm{~min}^{-1}$ and the composition of the mixture varied from $0 \%$ to $30 \% \mathrm{H}_{2}$. The number of cycles to be analysed was set to 130 . Figure 1 shows the plot of the pressure during combustion near top dead centre (TDC). The pressure curves in relation to mixture composition were collected as average values from 130 cycles. The results show that the addition of hydrogen increases the rate of combustion, which results in an earlier (steeper) pressure rise. The addition of $20 \% \mathrm{H}_{2}$ will increase the pressure by about $0.09 \mathrm{MPa}$ and the angle of maximum pressure reached is shifted by about $1.5^{\circ} \mathrm{CA}$ closer to TDC. The higher the content of hydrogen, the higher the maximum pressure and the more the value of the angle of maximum pressure will move towards TDC. One of the parameters affecting the mechanical stress of the engine is the rate of pressure rise. With increasing hydrogen content the rate of pressure rise increases and achieves maximum value even earlier. With running on natural gas the max. value is $0.223 \mathrm{MPa} /{ }^{\circ} \mathrm{CA}$ at an angle $347.3^{\circ} \mathrm{CA}$, and with $20 \%$ added vol. of $\mathrm{H}_{2^{\prime}}$ the value increases to $0.232 \mathrm{MPa} /{ }^{\circ} \mathrm{CA}$ at an angle of $345.8^{\circ} \mathrm{CA}$.

\begin{tabular}{|l|c|c|c|c|c|}
\hline \multicolumn{2}{|c|}{ Parameter } & H2NG0 & H2NG10 & H2NG20 & H2NG30 \\
\hline Percentage of $\mathbf{H}_{2}$ in mixture & {$[\%$ vol. $]$} & 0 & 10 & 20 & 30 \\
\hline Molar mass & {$\left[\mathrm{kg} \cdot \mathrm{kmol}^{-1}\right]$} & 16.64 & 15.18 & 13.72 & 12.25 \\
\hline Density $\left(\mathbf{2 0}{ }^{\circ} \mathbf{C}, \mathbf{1 0 1} \mathbf{3 2 5} \mathbf{~ P a}\right)$ & {$\left[\mathrm{kg} \cdot \mathrm{m}^{-3}\right]$} & 0.705 & 0.643 & 0.582 & 0.520 \\
\hline Theoretical amount of air & {$\left[\mathrm{kg} \cdot \mathrm{kg}^{-1}\right]$} & 17.00 & 17.23 & 17.51 & 17.86 \\
\hline Lower calorific value of a fuel & {$\left[\mathrm{kJ} \cdot \mathrm{kg}^{-1}\right]$} & 48825 & 49770 & 50916 & 52336 \\
\hline Lower calorific value of a fuel & {$\left[\mathrm{kJ} \cdot \mathrm{m}^{-3}\right]$} & 34412 & 32018 & 29624 & 27232 \\
\hline Calorific value of air mixture & {$\left[\mathrm{kJ} \cdot \mathrm{m}^{-3}\right]$} & 3135 & 3128 & 3122 & 3115 \\
\hline
\end{tabular}

TABLE 1: Basic parameters of mixtures of natural gas with hydrogen. TABUL'KA 1: Základné parametre zmesi zemného plynu s vodíkom.

\begin{tabular}{|l|c|}
\hline Principle of work & Spark ignition \\
\hline Number of cylinders, configuration & 2, inline \\
\hline Swept volume $\left[\mathrm{cm}^{3}\right]$ & 686 \\
\hline Bore/stroke $[\mathrm{mm} / \mathrm{mm}]$ & $75 / 77.6$ \\
\hline Compression ratio $[-]$ & $12.5: 1$ \\
\hline Crankshaft throw angle $\left[{ }^{\circ}\right]$ & 360 \\
\hline Valve gear/drive & OHC /Belt drive system \\
\hline Intake & atmospheric (non-supercharged) \\
\hline Preparation of mixture & $\begin{array}{c}\text { External, in mixer } \\
\text { (system VOILA Plus) }\end{array}$ \\
\hline
\end{tabular}

TABLE 2: Basic characteristics of the Lombardini LGW 702 combustion engine.

TABUL'KA 2: Základná charakteristika spal'ovacieho motora Lombardini LGW 702.

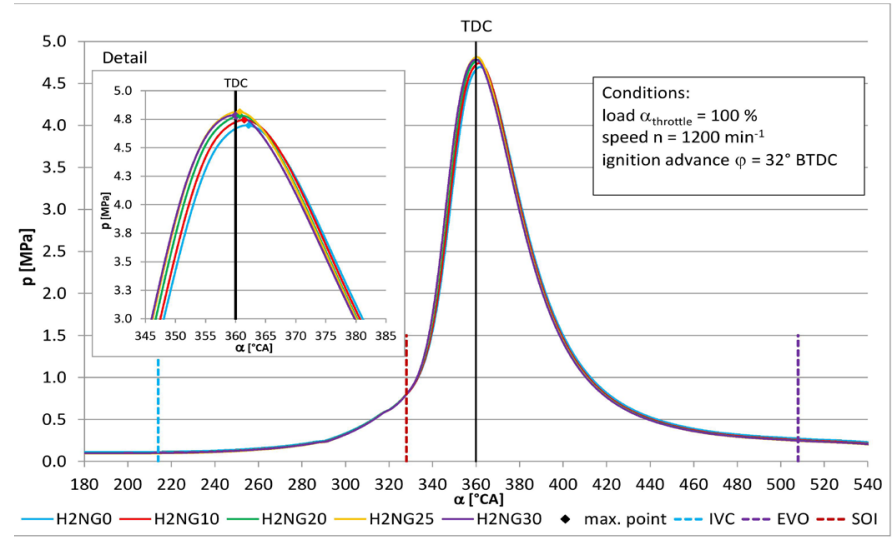

FIGURE 1: Plots of pressures in the combustion engine at various mixture compositions ( $\mathrm{H} 2 \mathrm{NGO}-\mathrm{H} 2 \mathrm{NG} 30$ ), with marked maximum values of pressure. OBRÁZOK 1: Priebehy tlakov v spal'ovacom priestore pre rôzne zloženie zmesi (H2NG0 - H2NG 30) s vyznačením maximálnej hodnoty tlaku. 
Another feature that has a significant impact on the stability of operation of the combustion engine is the coefficient of variability (COV). The coefficient of variability represents a relative measure of variability, and gives us an idea of engine smoothness. From measured time, or in other words the relationship between angle and pressure in the combustion chamber, it is possible to evaluate the nature of cycle-to-cycle variability. Previous research suggests that the combustion of natural gas leads to COV increase because it has a low flame propagation speed and a higher energy spark is needed. In contrast, the addition of hydrogen leads to faster combustion of the fuel because hydrogen has a higher flame speed. Also its relatively low density and high diffusivity means a homogeneous mixture

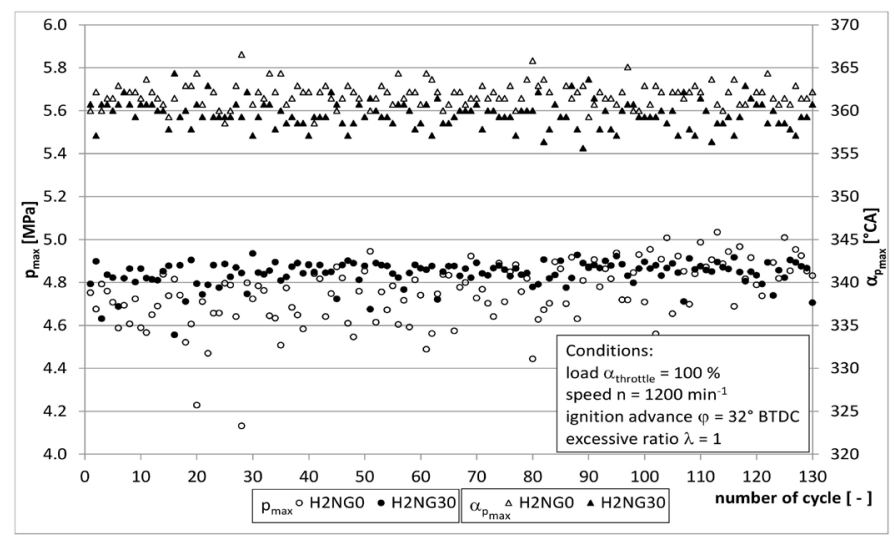

FIGURE 2: Depiction of maximum pressures achieved in the combustion chamber with respective angles of the crankshaft during a given cycle over 130 cycles.

OBRÁZOK 2: Zobrazenie maximálneho dosahovaného tlaku v spal'ovacom priestore a jemu prislúchajúcemu uhlu klukového hriadel'a v danom cykle v rozsahu cyklov 130.

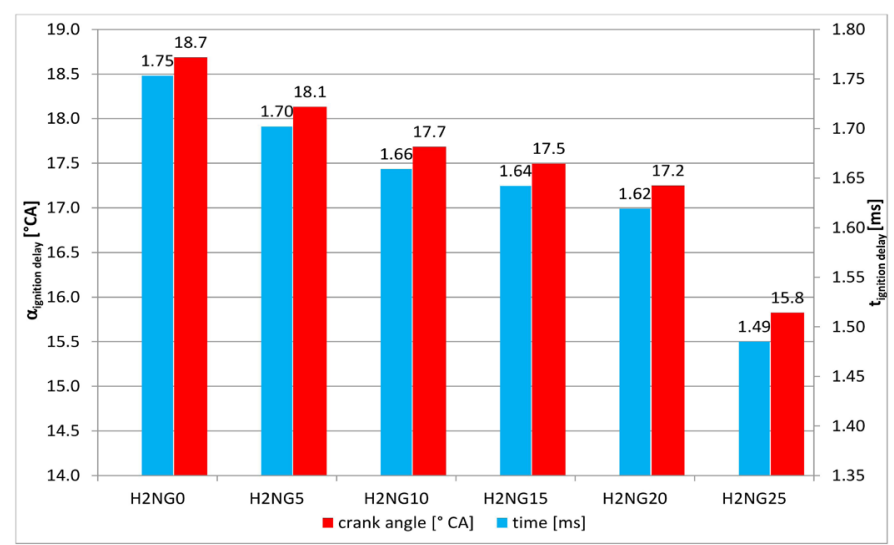

FIGURE 3: Ignition delay expressed in degrees of crankshaft angle or by period of duration for various compositions of mixtures of natural gas with hydrogen $\left(n=1800 \mathrm{~min}^{-1}, \lambda=1, \alpha_{\text {throttle }}=100 \%\right)$.

OBRÁZOK 3: Prietah zážihu vyjadrený v stupňoch otočenia klukového hriadel'a resp. časom trvania pre rôzne zloženia zmesi zemného plynu a vodíka $\left(n=1800 \mathrm{~min}^{-1}, \lambda=1, a_{\text {throttle }}=100 \%\right.$ ). can be created more easily. Among the most important factors that may affect cycle-to-cycle variability are: composition of the mixture $\left(\mathrm{H}_{2} / \mathrm{NG}\right.$ ratio, ratio air/fuel, mixture non-homogeneity, residual gas from previous cycle), physical factors (combustion chamber geometry, compression ratio) as well as ignition factors (ignition system, spark plugs, flow profile of filling in the area of spark plug sparking). The coefficient of variability is calculated as a ratio of the standard deviation to the arithmetic mean value of the selected data, and has the following form:

$$
\operatorname{COV}=\frac{\sqrt{\frac{1}{n-1} \sum_{i=1}^{n}\left(x_{i}-\bar{x}\right)^{2}}}{\bar{x}} \cdot 100 \quad[\%]
$$

Minimizing cycle variability contributes to increased performance for the same fuel consumption.

Figure 2 shows the values achieved for the maximum pressure and angle during 130 cycles. The average value for the mixture H2NG0 $p_{\text {max }}$ is $4.75 \mathrm{MPa}$ and the average angle $\alpha_{\text {pmax }}$ for this pressure is $361.8^{\circ} \mathrm{CA}$. For the mixture H2NG30 the average maximum pressure is $4.85 \mathrm{MPa}$ at angle $359.7^{\circ} \mathrm{CA}$. Expressed via the coefficient of variability of the maximum pressure, the mixture $\mathrm{H} 2 \mathrm{NGO}$ has the value $\mathrm{COV}_{\text {pmax }}=3.05 \%$ and the mixture $\mathrm{H} 2 \mathrm{NG} 30$ has $\mathrm{COV}_{\text {pmax }}$ value $=1.24 \%$. It follows that the addition of $30 \%$ of hydrogen into the mixture results in the coefficient of variability being reduced to approximately half of its previous value. If COV was calculated from values of indicated mean effective pressures then the differences between $\mathrm{H} 2 \mathrm{NGO}$ and H2NG30 were negligible with values 4.16 or $4.18 \%$.

The pressure analysis allowed for calculation of ignition delay over 130 cycles. The value between the moment of spark discharge and the moment when the curve of pressure started to differ from the curve representing the engine compression line was taken as the value of ignition delay. The condition under which the two curves started to diverge from each other had the value $25 \mathrm{kPa}$, as related to the variability of individual cycles. Figure 3 shows the period of ignition delay, expressed both by in terms of time and angle for various compositions of H2NG. Adding hydrogen to the blend shortens the period of the delay for the mixture H2NG25 by approximately $3^{\circ} \mathrm{CA}$, i.e. $0.3 \mathrm{~ms}$ at a speed of $1800 \mathrm{~min}^{-1}$, compared to the values for natural gas ( $\mathrm{H} 2 \mathrm{NGO}$ ).

Figure 4 shows the analysis of mass fraction of fuel burned (MFB) for various mixture compositions. The curves of MFB were calculated using the Rassweiler-Withrow method, building the increase of pressure during combustion as a combination of pressure caused by actual combustion and pressure caused by a change of volume of cylinder. The horizontal $(x)$ axis shows the relative time of burning, i.e. the actual angle during burning relative to the overall angle of burning. This method provided discrete values of time necessary for burning the fuel. As a follow-up, the coefficients of Wiebe function were calculated by non- 


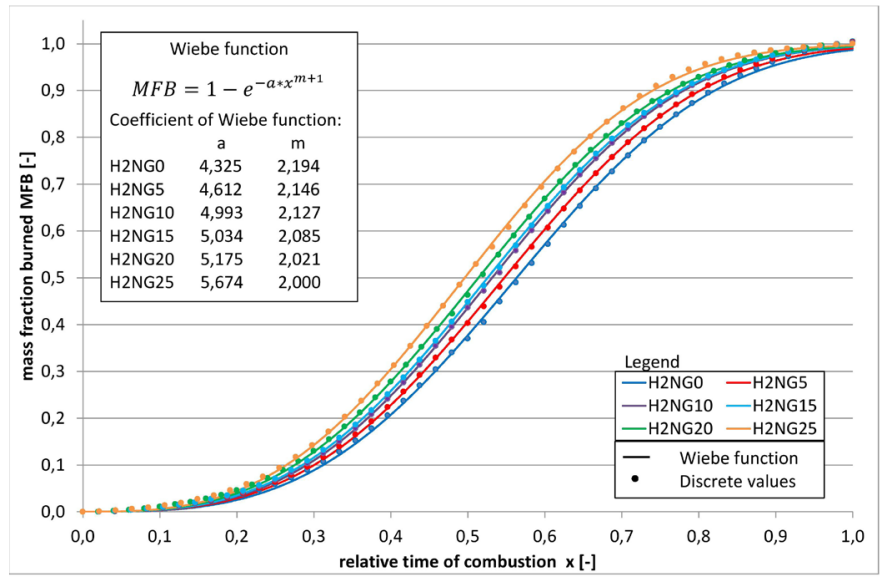

FIGURE 4: Curves of the mass fraction of fuel burned (discrete values and Wiebe function) in relation to relative time of combustion for various mixtures of natural gas with hydrogen $\left(n=1800 \mathrm{~min}^{-1}, \alpha_{1 \mathrm{~A}}=32^{\circ} \mathrm{CA}\right.$, $\lambda=1, \alpha_{\text {throttle }}=100 \%$, MFB - Mass Fraction Burned).

OBRÁZOK 4: Priebeh pomerného spáleného množstva paliva (diskrétne hodnoty a Wiebeho funkcia) vzhl'adom na pomerný čas spalovania pre rôzne pomery zmesi zemného plynu s vodíkom ( $\mathrm{n}=1800 \mathrm{~min}^{-1}$, $\alpha_{\mathrm{IA}}=32^{\circ} \mathrm{CA}, \lambda=1, \alpha_{\text {throttle }}=100 \%$, MFB - pomerné spálené hmotnostné množstvo paliva).

-linear regression analysis, which is the method most commonly used to determine the characteristics of fuel burning. As can be seen in Figure 4, increasing values of hydrogen result in better and more complete burning of fuel as well as a faster burning of a larger amount of the fuel. The period in which $50 \%$ of H2NG25 fuel burns at 1800 min-1 is faster by $3.6^{\circ} \mathrm{CA}$ compared to the combustion of natural gas alone.

\section{OPTIMUM ANGLE OF IGNITION ADVANCE}

The value of the optimum ignition advance depends mainly on the nature of flame propagation through the combustion chamber. The flame propagation depends on many parameters such as engine speed, engine load, engine temperature, intake temperature, fuel composition, air excess ratio and amount of residual exhaust gas. An admixture of hydrogen with natural gas leads to a faster burning of the mixture, hence to an earlier increase in pressure. In order to achieve maximum torque, thus overall (effective) efficiency of the engine, it was necessary to move the angle of ignition advance closer to the top dead centre with increasing content of hydrogen. Figure 5 shows the relationship between optimum angle of ignition advance and the content of hydrogen in the mixture for the entire range of engine speeds. At low rpm speeds we were not successful in measuring the optimum ignition advance, as we were limited by the minimum advance that could be set on the ignition system used $\left(15^{\circ} \mathrm{CA} \mathrm{BTDC}\right)$. Generally, the rule for each fuel is that with acceleration the ignition advance will be lifted away from TDC.
By adding $20 \%$ of hydrogen to natural gas the value of advance will be lifted by about $5.5^{\circ} \mathrm{CA}$ closer to TDC.

Figure 6 shows a section of the graph of optimum ignition advance through the various mixture compositions, along with the plot of torque at optimum advance. Increasing the proportion of hydrogen $H_{2}$ decreases the torque $M_{t}$. An increase in hydrogen by $10 \%$ leads to a decrease in torque on average by $0.5 \%$ and an increase of $20 \%$ of hydrogen results in a torque decrease on average by $1.3 \%$ across the whole range of revolutions. The maximum torque for operation on natural gas is $44.6 \mathrm{~N} . \mathrm{m}$ at $1800 \mathrm{~min}^{-1}$. At this rpm speed the H2NG10 operation also reaches its highest maximum of $44.3 \mathrm{~N} . \mathrm{m}$. The maximum torque for mixture H2NG20 is $44.1 \mathrm{~N} . \mathrm{m}$ in the engine speed range 1600 to $1800 \mathrm{~min}^{-1}$.

The value of the volumetric efficiency shown in Figure 7 is also a reference parameter characterizing the operation of the internal combustion engine. The volumetric efficiency is determined as the ratio of the amount of fresh charge that passes along the filling tract, to the theoretically possible amount of the charge that corresponds to the swept volume at ambient conditions $\left(29^{\circ} \mathrm{C}, 97989 \mathrm{~Pa}\right)$. For all cases of mixture composition $(0-30 \%$ $\mathrm{H}_{2}$ ) the shape of the curve of volumetric efficiency was similar across the whole range of engine speeds, with the maximum value reached at $1600 \mathrm{~min}^{-1}$. When burning pure natural gas the engine had volumetric efficiency $83.5 \%$; however, adding $10 \%$ of hydrogen dropped this value to $81.2 \%$. Increasing the proportion of hydrogen to $20 \%$ decreased the volumetric efficiency to the value $80.1 \%$.

Figure 8 shows the graph of brake specific fuel consumption and effective efficiency of the engine. As can be seen from the fuel consumption curve, the adding of hydrogen decreases the consumption across the entire rpm range. Increasing the amount of hydrogen to $10 \%$ leads to a decrease in the specific consumption, across the entire rpm range on average by $1.7 \%$. An increase in hydrogen content to $20 \%$ decreases the value of specific consumption on average by $3.5 \%$ compared to operation on pure natural gas.

With adding $10 \%$ of hydrogen to natural gas the effective efficiency increases, on average by $0.5 \%$ across the whole $\mathrm{rpm}$ range. Increasing the proportion of hydrogen by another $10 \%$ increases the efficiency on average by $1.2 \%$.

\section{ANALYSIS OF EXHAUST GASES}

Increasing the proportion of hydrogen in the mixture with natural gas has a positive effect on reduction of $\mathrm{CO}$ and $\mathrm{CO}_{2}$. Figure 9 shows a graph of basic emissions $\left(\mathrm{CO}, \mathrm{CO}_{2}, \mathrm{NO}_{x^{\prime}} \mathrm{O}_{2}\right)$ measured after the three-way catalytic converter in relation to the coefficient of air excess ratio for mixtures $\mathrm{H} 2 \mathrm{NGO}$ and $\mathrm{H} 2 \mathrm{NG15}$, at engine speed $1600 \mathrm{~min}^{-1}$. Increasing the content of hydrogen in the mixture with natural gas leads to a reduction 


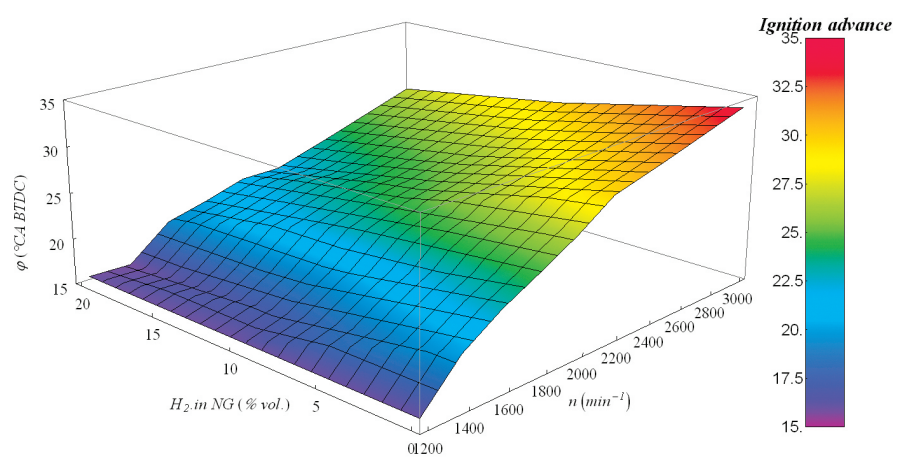

FIGURE 5: Plot of optimum angle of ignition advance to obtain maximum torque (MBT) for various mixture compositions (H2NG) in relation to rpm. OBRÁZOK 5: Priebeh optimálneho uhlu predzápalu pre dosiahnutie maximálneho krútiaceho momentu (MBT) pre rôzne zloženie zmesi (H2NG) v závislosti od otáčok.

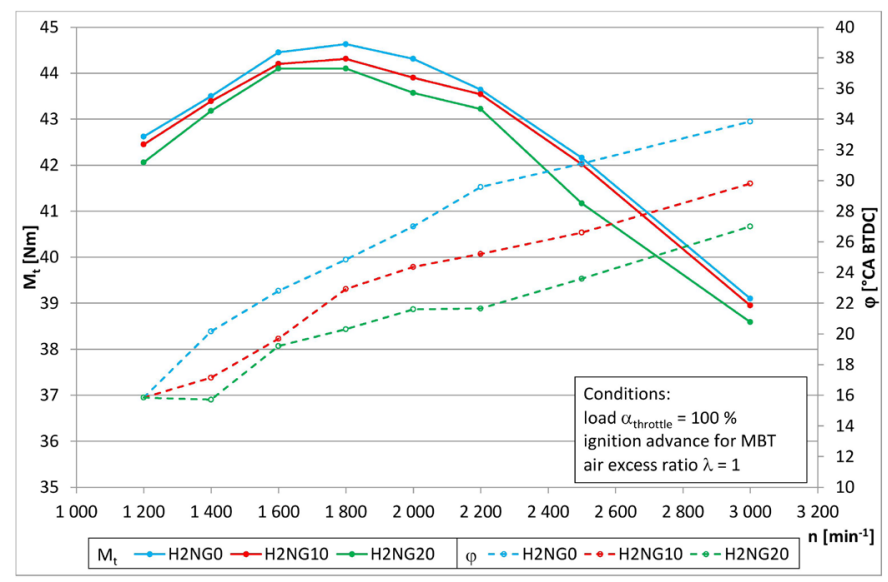

FIGURE 6: Graph of torque and optimum angle of ignition advance (MBT) for various mixture compositions against rpm.

OBRÁZOK 6: Priebeh točivého momentu a optimálneho uhlu predzápalu (MBT) pre rôzne zloženie zmesi v závislosti od otáčok.

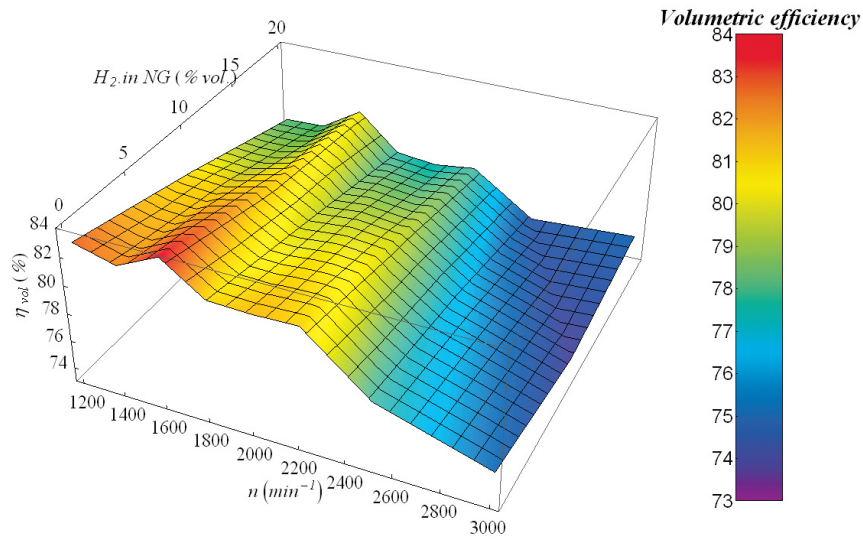

FIGURE 7: Graph of volumetric efficiency for various mixture compositions (H2NG), in relation to rpm speed of the Lombardini LGW 702 combustion engine.

OBRÁZOK 7: Priebeh volumetrickej účinnosti pre rôzne zloženie zmesi (H2NG) v závislosti od otáčok spalovacieho motora Lombardini LGW 702. in carbon content in mixture $\mathrm{H} 2 \mathrm{NG}$, thereby a results in lower production of carbon dioxide. From the graph it can be seen that the $\mathrm{CO}_{2}$ decreases on average by $0.8 \%$ vol. An increased proportion of hydrogen in the mixture does not have any significant effect on the formation of carbon monoxide or on the presence of free oxygen from the air. The formation of $\mathrm{CO}$ in the area of rich mixture, where there is a lack of oxygen for a complete conversion of $\mathrm{CO}$ to $\mathrm{CO}_{2}$, has the same character as for mixture $\mathrm{H} 2 \mathrm{NGO}$ and mixture H2NG15. Formation of nitrogen oxides $\mathrm{NO}_{x}$ is most significant in the area of slightly lean mixtures where the combustion temperature is the highest and a relative excess of free oxygen occurs. As seen from the curve for $\mathrm{NO}_{x^{\prime}}$ as the proportion of hydrogen increases the formation of $\mathrm{NO}_{x}$ also increases, which relates to the temperatures of combustion. In lean mixtures nitrogen oxides decrease in occurrence with decreasing temperature of combustion for both mixtures. From Figure 9 it can be concluded that the addition of $15 \%$ of hydrogen significantly increases flammability in the area of lean mixtures, which still allows for relatively cultivated operation of the internal combustion engine. This limit for the mixture $\mathrm{H} 2 \mathrm{NG} 15$ has the value $\lambda=1.5$. With increased proportion of hydrogen the limit will have the tendency to extend.

\section{CONCLUSION}

An admixture of hydrogen with natural gas has a number of significant and positive effects on the overall performance of a spark ignition internal combustion engine. The following points summarize the effects of hydrogen and how it influences the running and performance of a spark ignition engine:

- with increasing proportion of hydrogen in the mixture the value of maximum pressure increases and the angle at which the value reaches its maximum moves closer to top dead centre,

- the value that characterises the rate of pressure rise increases with increasing ratio $\mathrm{H}_{2} / \mathrm{NG}$, and the crank angle at which maximum pressure occurs also shifts,

- with added hydrogen to the mixture the coefficient of variability of maximum pressure decreases,

- increasing proportion of $\mathrm{H}_{2}$ decreases the optimum value of ignition advance for maximum torque,

- adding $10 \%$ of hydrogen causes the torque value at MBT ignition advance to decrease on average by $0.5 \%$ across the rpm range,

- the effective operation of the internal combustion engine increases with increased proportion of hydrogen in the gas mixture,

- with $10 \%$ added $\mathrm{H}_{2}$, the volumetric efficiency decreases by about $2 \%$ across the rpm range, 
- addition of hydrogen to the fuel mixture leads to lower concentration of carbon dioxide and unburned hydrocarbons in the exhaust gases, while the proportion of water vapour and nitrogen oxides increase,

- a higher proportion of hydrogen increases the flammability limit of the mixture and lifts it to the area of lean mixtures.

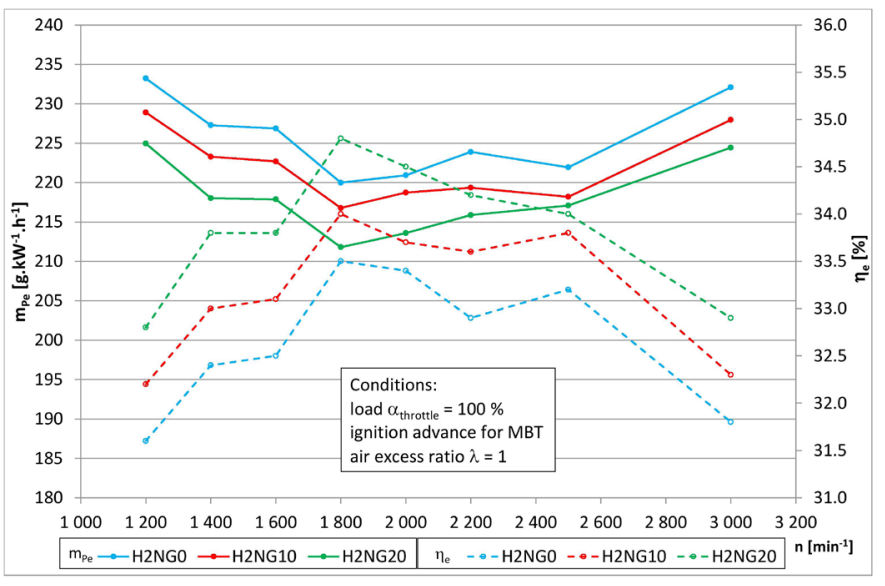

FIGURE 8: Graph of brake specific fuel consumption and effective efficiency of the LGW 702 combustion engine for various mixture compositions, with respect to rpm.

OBRÁZOK 8: Priebeh mernej efektívnej spotreby paliva a efektívnej účinnosti spal'ovacieho motora LGW 702 pre rôzne zloženie zmesi v závislosti od otáčok.

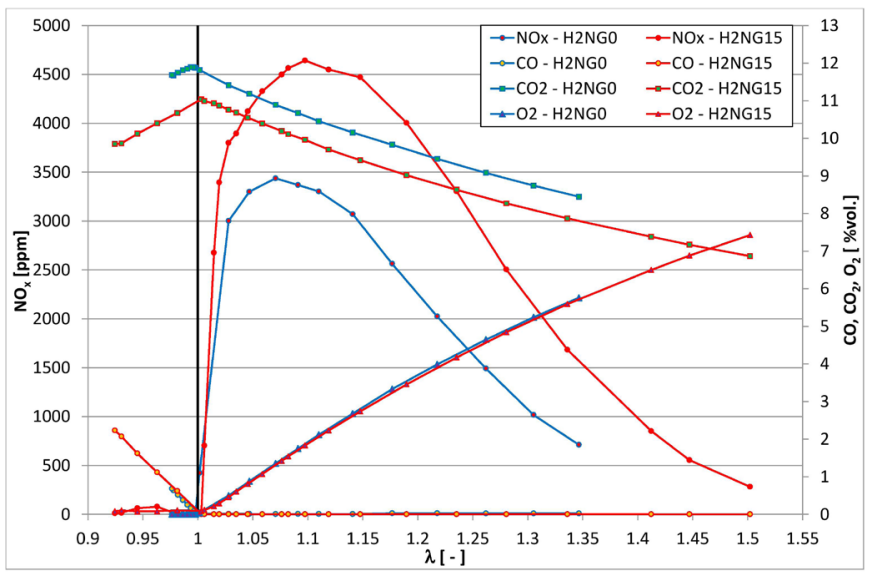

FIGURE 9: Composition of exhaust gases measured after the catalytic converter in relation to the coefficient of air excess ratio for mixture H2NG0 ( $0 \%$ vol. $\left.\mathrm{H}_{2}\right)$ and $\mathrm{H} 2 \mathrm{NG} 15\left(15 \%\right.$ vol. $\left.\mathrm{H}_{2}\right)$, at full load, ignition advance $28^{\circ}$ of CA before top dead centre, speed $1600 \mathrm{~min}^{-1}$. OBRÁzOK 9: Charakter zloženia výfukových plynov meraných za katalyzátorom v závislosti na súčiniteli prebytku vzduchu pre zmes H2NGO $\left(0 \%\right.$ vol. $\left.\mathrm{H}_{2}\right)$ a H2NG15 (15\% vol. $\left.\mathrm{H}_{2}\right)$ pri plnom zatažení, predstihu zapálenia $28^{\circ}$ pred HU a otáčkach $1600 \mathrm{~min}^{-1}$.

\section{ACKNOWLEDGEMENTS}

This work was supported by the Slovak Research and Development Agency under the contract No. APVV-0270-06 and under the contract No. APVV-0090-10.

\section{REFERENCES}

[1] Sierens R. (2000). Variable Composition Hydrogen/Natural Gas Mixtures for Increased Engine Efficiency and Decreased Emissions, Laboratory of Transport technology.

[2] Huang Z., Bing L. (2006). Experimental Study on Engine Performance and Emissions for an Engine Fueled with Natural Gas - Hydrogen Mixtures. Energy Fuels, pp. 2131-2136

[3] Bin H., Erjiang H., Zuohua H., Jianjun Z., Bing L., Deming J. (2009). Cycle-by-cycle variations in a spark ignition engine fueled with natural gas-hydrogen blends combined with EGR. International journal of hydrogen energy, Vol. 34, 2009, pp. 8405-8414, ISSN: 0360-3199

[4] Shuofeng W., Changwei J. (2012). Cyclic variation in a hydrogen-enriched spark-ignition gasoline engine under various operating conditions. International journal of hydrogen energy Vol. 37, pp. 1112-1119, ISSN: 0360-3199

[5] Ceviz M. A., Öner I. V., Kaya F., Karacali T. (2011). Analysis of the thermal efficiency and cyclic variations in a SI engine under lean combustion conditions. Journal of Thermal Science and Technology, pp. 121-127, ISSN: 1300-3615

[6] Jungsoo P., Hyoseok Ch., Soonho S., Kwang M. Ch. (2011). A numerical study of a methane-fueled gas engine generator with addition of hydrogen using cycle simulation and DOE method. International journal of hydrogen energy, Vol. 36, pp. 5153-5162, ISSN: 0360-3199

[7] Fanhua M., Yu W., Mingyue W., Haiquan L., Junjun W., Shangfen D., Shuli Z. (2008). Development and validation of a quasi-dimensional combustion model for $\mathrm{SI}$ engines fuelled by HCNG with variable hydrogen fractions. International journal of hydrogen energy, Vol. 33, pp. 4863-4875, ISSN: 0360-3199

[8] Keshavarz A., Chapman k., patil a. (2009). Experimental Study of Hydrogen Addition Impact on Emissions and Performance of a Natural Gas Fueled Engine. The Journal of Engine Research, Vol. 14, pp. 43-50, ISSN: 1735-5214

[9] [mariani A., morrone b, unich a. (2012). Numerical evaluation of internal combustion spark ignition engines performance fuelled with hydrogen - Natural gas blend. International journal of hydrogen energy, Vol. 37, pp. 2644-2654, ISSN: 0360-3199

[10] Chang W. (2002). An improved method of investigation of combustion parameters in a natural gas fuelled SI engine with EGR and $\mathrm{H} 2$ additives. PhD. Thesis, The University of Birmingham, England 